University for Business and Technology in Kosovo

UBT Knowledge Center

UBT International Conference

2016 UBT International Conference

Oct 28th, 9:00 AM - Oct 30th, 5:00 PM

\title{
Effects of Sustainable Materials in Construction, Environment and Health
}

\author{
Muhamet Ahmeti \\ University for Business and Technology, muhamet.ahmeti@ubt-uni.net \\ Mimoza Sylejmani \\ University for Business and Technology, mimoza.sylejmani@ubt-uni.net \\ Vlora Aliu \\ University for Business and Technology, vlora.aliu@ubt-uni.net
}

Follow this and additional works at: https://knowledgecenter.ubt-uni.net/conference

Part of the Engineering Commons

\section{Recommended Citation}

Ahmeti, Muhamet; Sylejmani, Mimoza; and Aliu, Vlora, "Effects of Sustainable Materials in Construction, Environment and Health" (2016). UBT International Conference. 17.

https://knowledgecenter.ubt-uni.net/conference/2016/all-events/17

This Event is brought to you for free and open access by the Publication and Journals at UBT Knowledge Center. It has been accepted for inclusion in UBT International Conference by an authorized administrator of UBT Knowledge Center. For more information, please contact knowledge.center@ubt-uni.net. 


\title{
EFFECTS OF SUSTAINABLE MATERIALS IN CONSTRUCTION, ENVIRONMENT AND HEALTH
}

\author{
Muhamet Ahmeti ${ }^{1}$, Mimoza Sylejmani ${ }^{2}$, Vlora Aliu ${ }^{2}$ \\ UBT - Higher Education Institution, Lagjja Kalabria, 10000 p.n., \\ Prishtine, Kosovo \\ $\left\{\right.$ muhamet.ahmeti $^{1}$, mimoza.sylejmani ${ }^{2}$, vlora.aliu $\left.{ }^{2}\right\} @$ ubt-uni.net
}

\begin{abstract}
In this paper it is presented a definition of sustainable construction from ecological aspect, characterized by reducing the impact of different materials in the environment during construction, but also during the whole lifetime of use of buildings.

To assess the impact of materials on health and environment is necessary to examine all phases from beginning of the materials manufacturing till the insertion to the construction, including the use of natural resources for the production of construction products, necessary energy for production, amount of release and $\mathrm{CO}_{2}$ emissions (carbon dioxide) in different stages, methods of construction, use of construction and in the end demolition and recycling.

In this paper are presented aspects of a sustainable building with a particular approach to the selection of construction materials and the awareness raise about the impact of materials on environment and health during the whole life of using the facilities. Also it is presented sustainable construction and environment, materials that affecting and the conditions of the different materials using during construction in Kosovo. With a special emphasis also presented the impact of materials on our health, recent research regarding the materials using in constructions and the difference between the old and new constructions in terms of human health. The difference between buildings constructed decades ago and buildings constructing now.
\end{abstract}

Keywords: Sustainability, sustainable construction, materials, sustainable materials, $\mathrm{CO}_{2}$ emissions.

\section{INTRODUCTION}

With increasing industrialization and rapid development have increased the demand for a clean environment as that can be met by improving production technologies to materials and transforming them into sustainable and environmentally conscious.

The concept of sustainability is defined by the Earth Summit in Rio de Janeiro in 1992 . (United Nations Conference on Environment and Development (UNCED), Rio de Janeiro, 3-14 June 1992 ), as a concept of activity that takes place in accordance with environmental laws.

Construction is one activity that consumes the greatest amount of natural resources (stone, wood, gravel, clay, etc.), So that is one of the main goals for all scientists and researchers to find alternative sources of raw materials for construction in the future, according to sustainability criteria ..

In this paper is give an overview of sustainable building in the context of the environment, taking as a basis some material such as concrete and its components and their role in sustainable building as well as 
Book of Proceedings

International Conference on Civil Engineering, Infrastructure and Environment

a detailed presentation of the industry that steady for the production of concrete for the concrete environment.

Concrete as a building material was used mostly in the industry, we introduced today is the need to meet all aspects of sustainability: environmental, technological, economic and sociological. The paper presents some important examples of construction in terms of sustainability that can contribute to the production of concrete.

Also I have presented some examples of buildings in the world in which they are applying the rules of environmentally sustainable concrete. (United Nations Conference on Environment and Development (UNCED), Rio de Janeiro, 3-14 June 1992 ),

\section{The Earth Summit} SUSTAINABLE DEVELOPMENT

\section{Globalization}

\section{Development}

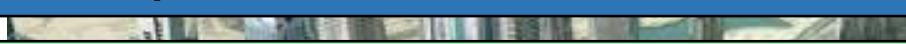

\section{Construction industry}

\section{Building materials industry}

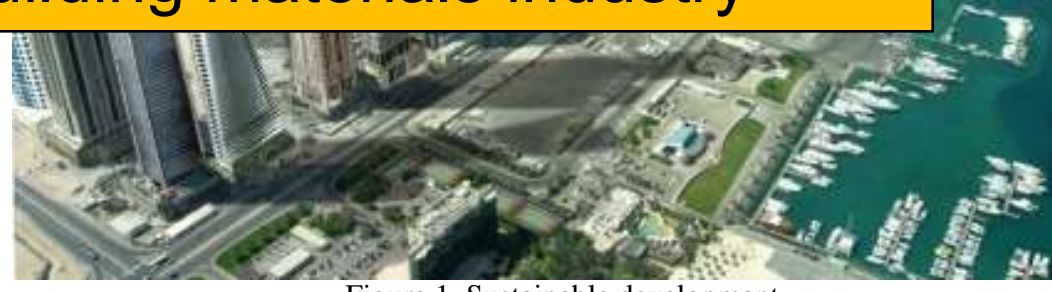

Figure 1. Sustainable development.

\subsection{SUSTAINABLE DEVELOPMENT}

Knowing the problems of environmental pollution from all aspects (environmental, economic, technological and social), then it is possible to create a technology that is environmentally sustainable. Sustainability is a way of life, access to overall economic activity in accordance with the earth's ecosystem that needs to have a vision of development.

The basic principle of sustainable development in construction is to use less natural resources and creating less by Earth hazardous waste. Environmental protection and energy saving become the world's problems in all fields of technology. 
In theoretical considerations of sustainability, there are three aspects: environmental, economic, sociological, and each of these aspects contains a number of sub-groups or meetings.
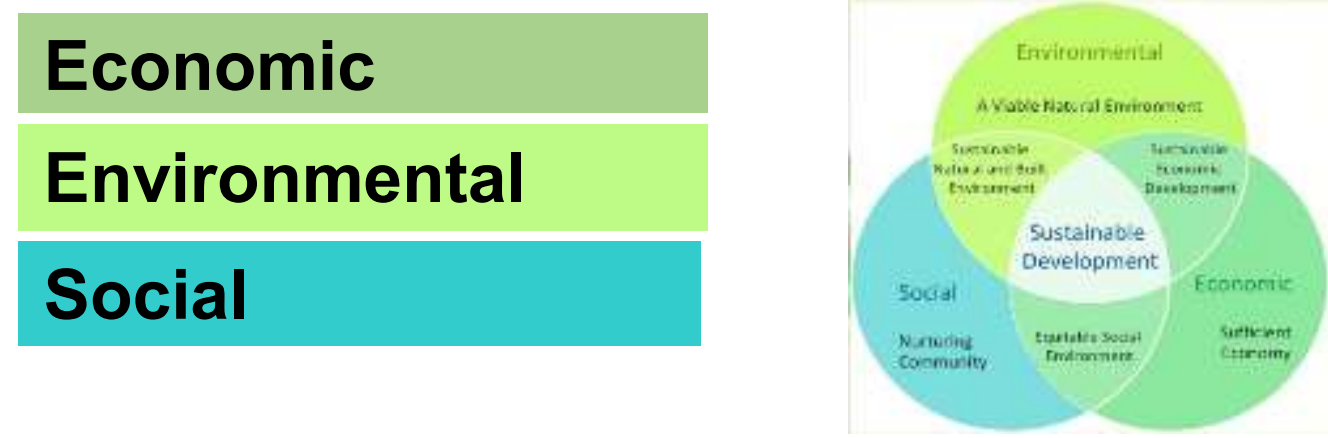

Figure 2. Sustainable development.

\subsection{SELECTION OF CONSTRUCTION MATERIAL AND SUSTAINABLE DEVELOPMENT}

\subsubsection{Achieving sustainable development goals requires a combination of many factors:}

- Method of energy saving,

- Improving the use of material,

- $\quad$ Reuse of material ,

- Emissions control of harmful substances.

The goals of sustainable construction:

- Resource efficiency and energy efficiency,

- Reduction of CO2 emissions, and different gases ,

- Pollution prevention,

- Noise Reduction ,

- Quality improve of the indoor air,

- Harmonization with environment.

Amount of construction wastes in EU

- 850 million tons per year

- $31 \%$ of total waste production in EU 
Book of Proceedings

International Conference on Civil Engineering, Infrastructure and Environment

Table 1. Amount of producing the recycled materials in EU in 2009

\begin{tabular}{|c|c|c|c|c|c|}
\hline & Produced amount & $\begin{array}{c}\text { Actual recycled } \\
\text { amount }\end{array}$ & $\begin{array}{c}\text { Amount which are } \\
\text { not recycled }\end{array}$ & Recycled limit & $\begin{array}{l}\text { Percentage of } \\
\text { recycling }\end{array}$ \\
\hline $\mathrm{EU}$ & Million tons & Million tons & Million tons & \% & \% \\
\hline The packaged waste & 82,3 & 48,1 & 34,1 & 55 & 58,7 \\
\hline Vehicles and old tires & 6,1 & 4,5 & 1,6 & 80 & 73,8 \\
\hline Electric waste & 6,7 & 1,5 & 5,2 & $50-75$ & 22,8 \\
\hline Municipality waste & 258 & 970 & 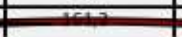 & T & 37,6 \\
\hline $\begin{array}{l}\text { Waste from the bulldings } \\
\text { deconstruction including } \\
\text { excavation }\end{array}$ & & 554 & 342 & 70 & 61. \\
\hline $\begin{array}{l}\text { General waste which are } \\
\text { included in EU recycling goals }\end{array}$ & 1.249 & 705 & 544 & & 56,4 \\
\hline General wastes in EU & 2.800 & 1.070 & 1.730 & & 38,2 \\
\hline
\end{tabular}

\subsection{ECOLOGICAL SET-EVALUATION CRITERIA OF MATERIAL}

\subsubsection{Impact of construction material in environment:}

- The use of raw materials from nature,

- Production,

- Transportation,

- Fabricating,

- Explations,

- Recycling.

Impact on people:_Physical ,Chemical ,Direct,Indirect ,Short term ,Long term ,Psychic character

\subsection{IMPACT OF CONSTRUCTION MATERIAL IN ENVIRONMENT:}

The energy consumed and carbon dioxide produced by conventional and alternative materials

\subsubsection{General evaluation criteria of ecological and suitability of material:}

- The rate of environmental degradation by taking material from nature,

- Repair of damaged parts of nature,

- The degree of environmental pollution during the processing of building materials,

- Intensity of noise, protection needs and the possibility of mechanical damage to buildings in the surrounding area during the production of materials and due to their implementation,

- Emission of harmful substances and radiation materials,

- Length of material life - the need for reproduction,

- Energy used during extraction of raw materials, producing of the raw material,,

- The possibility of recycling the material. 


\subsubsection{CRITERIA FOR THE SELECTION OF BUILDING MATERIALS IN ENERGY TERMS}

The overall balance of energy - total energy of which some building materials, Spend length during their long-life:

- Supply and transport of raw materials (local materials have advantage - stone, wood, clay),

- Construction material production (steel and aluminum are the major energy consuming, while wood and bricks are the small energy expendable during processing),

- The energy consumed during transportation of material in workplace (light material advantage),

- The energy spent during the implementation of works in objects (light materials - easy to mount),

- Energy saved in the material staying in the facilities, which is necessary for maintaining the microclimate (Thermal insulation and thermo accumulative properties),

The possibility of recycling and energy required for recycling material.

\subsection{ENERGY ASPECT IN THE SELECTION OF BUILDING MATERIALS}

During the selection of construction material apart functionality, health aspects and other criteria is very important to take into account the overall balance of energy Cement - the energy needed to produce basic building materials

Table 1 : Energy required for the production of basic building materials.

\begin{tabular}{|l|c|c|}
\hline Material & KWh/t & 82.000 \\
\hline Steel & 10.500 & 1900 \\
\hline Cement & 1400 & 71000 \\
\hline Copper & 8000 & 15 \\
\hline Gravel & 9 & 1600 \\
\hline Lime & 1200 & 15000 \\
\hline Glass & 5700 & 14900 \\
\hline Ceramics & 6200 & 460 \\
\hline Concrete & 200 & 250 \\
\hline Concrete foam & 500 & 180 \\
\hline Glass wool & 6000 & 11000 \\
\hline Plastic & 11000 & 100 \\
\hline Wood & 190 & \\
\hline
\end{tabular}


Book of Proceedings

International Conference on Civil Engineering, Infrastructure and Environment

\subsubsection{CO2 emissions energy consumption and emissions of $\mathrm{CO} 2$ to simple materials and alternative}

- Once again we examine the basis of the process of carbon dioxide emissions from the cement industry.

- The level of carbon dioxide in the atmosphere is increasing. Contribution of $5 \%$ of the cement industry in increasing the amount of $\mathrm{CO} 2$ is significant since it comes from human activity.

- Technological process of cement production requires large amounts of energy, whether in form of heat from the burning of fossil bio even by electricity.

- The roasting process itself and processing of limestone as one of the core subjects of cement benefit associated with direct and indirect emissions of carbon dioxide.

\subsubsection{CONCRETE}

Being a very material consumed and the fact that its production is associated with higher emissions in the atmosphere, mainly $\mathrm{CO} 2$, it is important to take in study and scientific ways of reducing $\mathrm{CO} 2$ emissions from this industry. Construction material Concrete is definitely bio of the 20th century, due to its properties compared to other materials you use in the 21 st century will be unavoidable and growing. Normal concrete consists of cement $12 \%, 8 \%$ water and $80 \%$ of aggregate. So, if the production of concrete 1.5 billion tons of cement per year, at the same time is spent and 900 million water and 9 billion tons of sand and stone.

In addition to the problem of energy consumption during cement production and emission of large quantities of $\mathrm{CO} 2$, with concrete structures significant problem is their durability which is ultimately manifested as the disposal of construction waste.

In Europe produced more than 750 mil.m3 of concrete and this amount is increased from 7.5 to $8 \%$ for years, concrete material ready not it harms the environment, while the production of components of the trailer affects the environment. The porcelain annual for cement production is our 1.5 billion, and is expected that this amount due to globalization and the rapid industrialization of developing countries will grow to ma more than $8 \%$ per year.
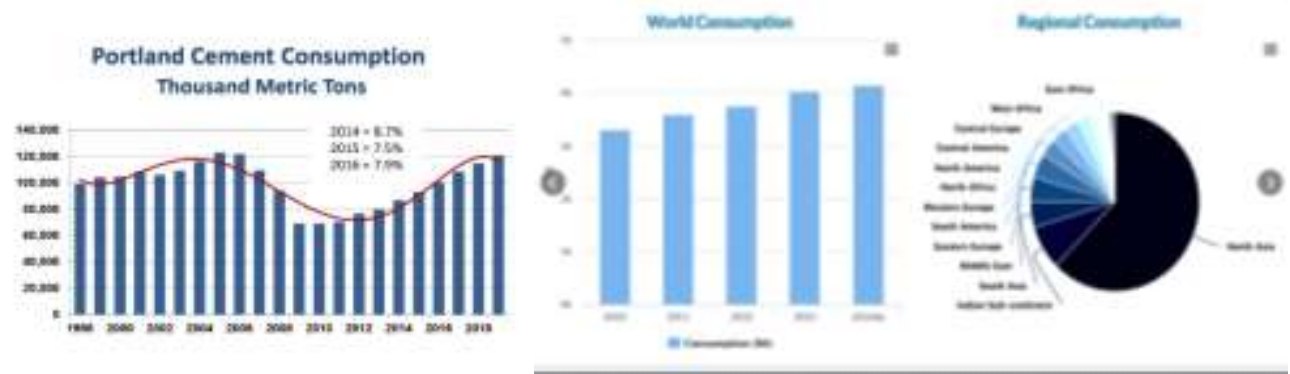

Figure 3. Sustainable development.

\subsubsection{USE OF CEMENT IN THE WORLD}

The total annual consumption of cement in Kosovo is 1052593 t. that every Kosovar spends approximately $500 \mathrm{~kg}$ of cement per year. 


\section{EFFECTS OF SUSTAINABLE MATERIALS IN CONSTRUCTION, ENVIRONMENT}

AND HEALTH

The target set for reducing the production of cement in the world until 2050

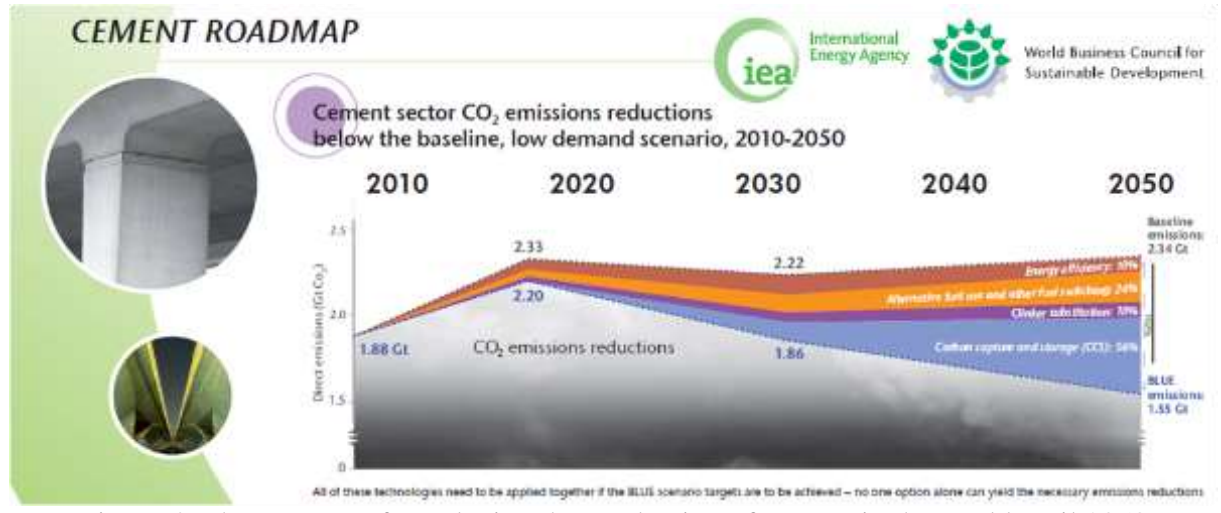

Figure 4. The target set for reducing the production of cement in the world until 2050

\subsection{REDUCTION OF CONCRETE IMPACTION IN ENVIRONMENT}

Reducing the use of Portland cement, using industrial products (fly ash, silica Fume , Slag Cement granules milled from the high furnace).The use of recycled materials instead of aggregate, reduces the use of inseparable materials and their impact on the environment. Porous concrete, can affect the function of sustainable storm water penetration, which in some cases may even have a positive effect,

Special concrete or special fabricated with supplements, can be build in permanent structures, lower cost maintenance, with little use of natural resources and their impact on the environment.

\subsubsection{SUPPLEMENTS TO CEMENT (SUBSTITUTES) Sustainability in Construction:}

According to statistics by the Conference of WOCAT (World of Coal Ash, 2013, US) global annual output of products from coal combustion process in 2010 was 780 Mt. Countries with the largest generation of CCP (abbreviation for coal combustion products) were China with $395 \mathrm{Mt}, 118$ Mt North America, India $105 \mathrm{Mt}$, Europe (EU15) to 52.6 Mt, 31.1 Mt Africa, Japan with $11.1 \mathrm{Mt}$.

This amount generated by the CCB, only $53 \%$, around $415 \mathrm{Mt}$ used as material in some sectors, mainly in concrete. The biggest beneficiary, as a percentage, was Japan with 96, 4\%, respectively $10.7 \mathrm{Mt}$.

Using the CCP in European countries was 90.9\%; US 42.1\%, China 67\%, Australia $45.9 \%$ and the rest of Asia $66 \%$.

In the case of Kosovo is to compare the amount of ash production of TPP in 2010, the reference year for comparison with these countries, which was $1.5 \mathrm{Mt}$, none kilogram of it has been reported to have been used in any sector, ie. The use of ash in Kosovo is $0 \%$. This has a negative effect on the environmental aspect as well as sustainable development. 
Book of Proceedings

International Conference on Civil Engineering, Infrastructure and Environment

Table 2 .Using Fly Ash as a Cement Replacement

\begin{tabular}{|l|c|c|c|}
\hline Application & Slag Cement & Fly Ash & Silica Fume \\
\hline General Concrete & $25-50 \%$ & $10-30 \%$ & $0-10 \%$ \\
\hline High-Performance & $35-65 \%$ & $15-30 \%$ & $5-15 \%$ \\
\hline Mass & $50-80 \%$ & $25-50 \%$ & $0-10 \%$ \\
\hline Precast/PS, Block & $20-50 \%$ & $10-30 \%$ & $0-15 \%$ \\
\hline $\begin{array}{l}\text { Note: The ranges shown are general estimates, and are meant to indicate typical ranges of SCMs in } \\
\text { concrete in conventional mixtures. The ranges shown can be exceeded, but special mix and construction } \\
\text { considerations are often necessary (e.g. high level of chemical admixtures, longer curing times, increases } \\
\text { in total amount of cementations materials). }\end{array}$ \\
\hline
\end{tabular}

Table 3 .Using Fly Ash as a Cement Replacement- Kosovo Case

\begin{tabular}{|l|c|c|c|c|c|}
\hline Vendi/rajoni & $\begin{array}{c}\text { Prodhimi I } \\
\text { CCP } \\
\text { (Mt) }\end{array}$ & $\begin{array}{c}\text { Përdorimi I } \\
\text { CCP } \\
\text { (Mt) }\end{array}$ & $\begin{array}{c}\text { Përdorimi } \\
(\%)\end{array}$ & $\begin{array}{c}\text { Prodhimi I } \\
\text { CCP për } \\
\text { banor } \\
\text { (t) }\end{array}$ & $\begin{array}{c}\text { Përdorimli } \\
\text { CCP për } \\
\text { banor (t) }\end{array}$ \\
\hline Kina & 395.0 & 265 & 67.1 & 0.29 & 0.20 \\
\hline SHBA & 118.0 & 49.7 & 42.1 & 0.37 & 0.16 \\
\hline India & 105.0 & 14.5 & 13.8 & 0.09 & 0.01 \\
\hline Europa EU (15) & 52.6 & 47.8 & 90.9 & 0.11 & 0.10 \\
\hline Federata Ruse & 26.6 & 5.0 & 18.8 & 0.19 & 0.04 \\
\hline Japonia & 11.1 & 10.7 & 96.4 & 0.09 & 0.08 \\
\hline Australia & 13.1 & 6.0 & 45.8 & 0.60 & 0.27 \\
\hline Kosova & 1.5 & 0 & 0 & 0.86 & 0. \\
\hline
\end{tabular}

The table shows that in Kosovo only in 2010 by the burning coal generated 9.4 Mt 1.5 Mt Hi TEC. Based on the latest population census in Kosovo in 2011 there were 1,739,825 inhabitants. Given these data, it appears that the generation of ash TPP CCP was about $860 \mathrm{~kg}$ per person.

The total annual consumption of cement in Kosovo is 1052593 t. that every Kosovar spends approximately $500 \mathrm{~kg}$ of cement per year. Kosovo produces about 3 million $\mathrm{m} 3$ of concrete, about 1.5-2 million cubic meters of concrete ready and the rest is spent on the production of concrete blocks and masonry mortars. 
EFFECTS OF SUSTAINABLE MATERIALS IN CONSTRUCTION, ENVIRONMENT AND HEALTH

Table 4 .Using Fly Ash as a Cement Replacement- Kosovo Case

\begin{tabular}{|l|c|c|c|c|c|c|}
\hline Mix ID & $\begin{array}{l}\text { Cimento } \\
\left(\mathrm{kg} / \mathrm{m}^{3}\right)\end{array}$ & $\begin{array}{l}\text { Hi TEC-I } \\
\left(\mathrm{kg} / \mathrm{m}^{3}\right)\end{array}$ & $\begin{array}{l}\text { Agregate } \\
\left(\mathrm{kg} / \mathrm{m}^{3}\right)\end{array}$ & $\begin{array}{l}\text { Uje } \\
\left(\mathrm{kg} / \mathrm{m}^{3}\right)\end{array}$ & $\begin{array}{l}\text { Shtesa TKK } \\
\left(\mathrm{kg} / \mathrm{m}^{3}\right)\end{array}$ & $\begin{array}{c}\text { Densiteti I } \\
\text { projektuar } \\
\left(\mathrm{kg} / \mathrm{m}^{3}\right)\end{array}$ \\
\hline MQDK- C & 300 & 0 & 1888 & 210 & 0 & 2398 \\
\hline MQDK-CTKK & 300 & 0 & 1888 & 190 & 1.2 & 2379 \\
\hline MQDK-15FA & 255 & 45 & 1888 & 190 & 1.2 & 2379 \\
\hline MQDK-20FA & 240 & 60 & 1888 & 190 & 1.2 & 2379 \\
\hline MQDK-25FA & 225 & 75 & 1888 & 190 & 1.2 & 2379 \\
\hline MQDK-30FA & 210 & 90 & 1888 & 190 & 1.2 & 2379 \\
\hline SCC Ec0- friendly & 400 & 100 & 1695 & 190 & 4.3 & 2389 \\
\hline
\end{tabular}

In table 5 are presented the ingredients of concrete measures designed for a cubic meter for reference and mixtures with different amounts of ash TPP. Concrete designed in this study, in terms of weight, is designed ordinary concrete.

Table 5 .Using Fly Ash as a Cement Replacement- Kosovo Case

\begin{tabular}{|c|c|c|c|c|c|c|c|c|}
\hline \multirow[t]{2}{*}{ ID e përzierjeve } & \multicolumn{4}{|c|}{$\begin{array}{c}\text { Agregati } \\
\text { ne fraksione } \\
\left(\mathrm{kg} / \mathrm{m}^{3}\right)\end{array}$} & \multirow[t]{2}{*}{$\begin{array}{l}\text { Çimento } \\
\left(\mathrm{kg} / \mathrm{m}^{3}\right)\end{array}$} & \multirow[t]{2}{*}{$\begin{array}{l}\text { HI TEC } \\
\left(\mathrm{kg} / \mathrm{m}^{3}\right)\end{array}$} & \multirow[t]{2}{*}{$\begin{array}{c}\text { Uje } \\
\left(\mathrm{kg} / \mathrm{m}^{3}\right)\end{array}$} & \multirow{2}{*}{$\begin{array}{c}\text { TKK } \\
\text { Super- } \\
\text { plastifikues } \\
\left(\mathrm{kg} / \mathrm{m}^{3}\right)\end{array}$} \\
\hline & 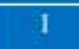 & II & III & IV & & & & \\
\hline MQDK-C & 944 & 290 & 322 & 332 & 300 & 0 & 210 & 0 \\
\hline MQDK-CTKK & 944 & 290 & 322 & 332 & 300 & 0 & 190 & 1.2 \\
\hline MQDK-15FA & 944 & 290 & 322 & 332 & 255 & 45 & 190 & 1.2 \\
\hline MQDK-20FA & 944 & 290 & 322 & 332 & 240 & 60 & 190 & 1.2 \\
\hline MQDK-25FA & 944 & 290 & 322 & 332 & 225 & 75 & 190 & 1.2 \\
\hline MQDK-30FA & 944 & 290 & 322 & 332 & 210 & 90 & 190 & 1.2 \\
\hline SCC Eco-friendly & 932 & 305 & 458 & 0 & 400 & 100 & 190 & 4.3 \\
\hline
\end{tabular}

Testing of fresh concrete density, ie testing method is standardized in the European standard EN 123506- Testing of fresh concrete. Item 6 of this standard defines the method of determining the density of concrete in wet conditions (EN 12350-6, 2009). Like any other method of testing other properties, as well as the density determination requires representative samples that meet the requirements of EN 12350-1 
Book of Proceedings

International Conference on Civil Engineering, Infrastructure and Environment

standard (EN 12350-1, 2009). Samples of concrete whose density define it must have been prepared in accordance with EN 12350-1.

Determination of fresh concrete density for mixtures without reference hi TEC and mixtures with different amounts of ash as a cement replacement is done in two ways: first by the standard method EN 12350-6 and the other was based on measurement measure mixtures of different samples and sample divided by the volume of the cube, cylinder, respectively. Previously, it can be said that the average values from both methods are highly compatible.

\subsection{SUSTAINABLE BUILDING CASES IN THE WORLD}

- Tsing Ma Bridege - where the two main pillars paper is used with low energy cement hydration by $70 \%$ during the granulated slag powder and $6 \%$, for the realization of the old lady that used ehte cement bridge that is composed of dust that flies and silica dust.
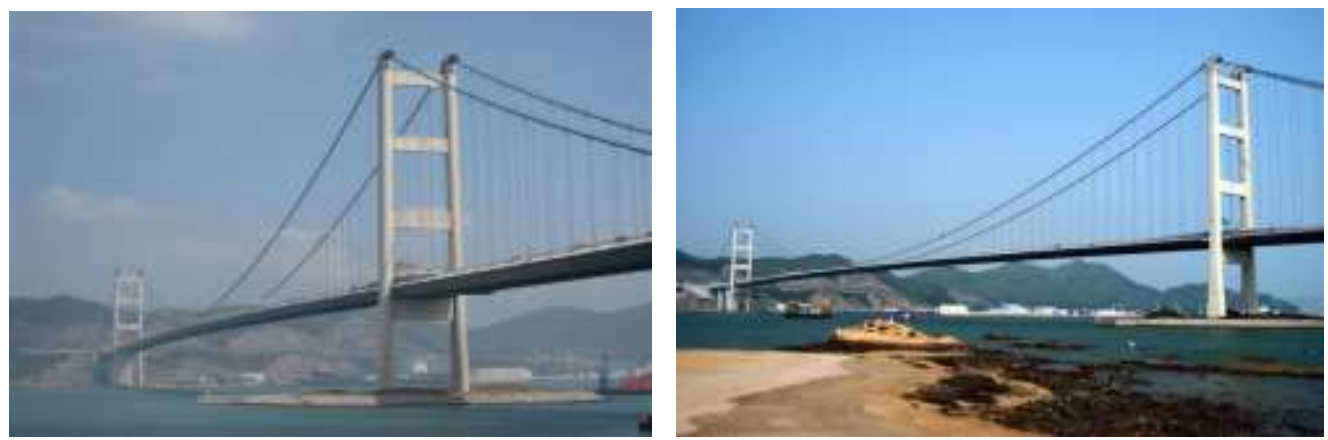

Foto 1 Tsing Ma Bridge : http://www.patnotebook.com/tsing-ma-bridge-photos-and-how-to-get

Baps Hindu Temple, Chicago, 2003 - Monolithic foundation for the realization of non-reinforced concrete are used with $3000 \mathrm{~m} 3$ cement clinker factor is 0.33 which met with reduced $\mathrm{CO} 2$ emissions to around $800 \mathrm{t}$

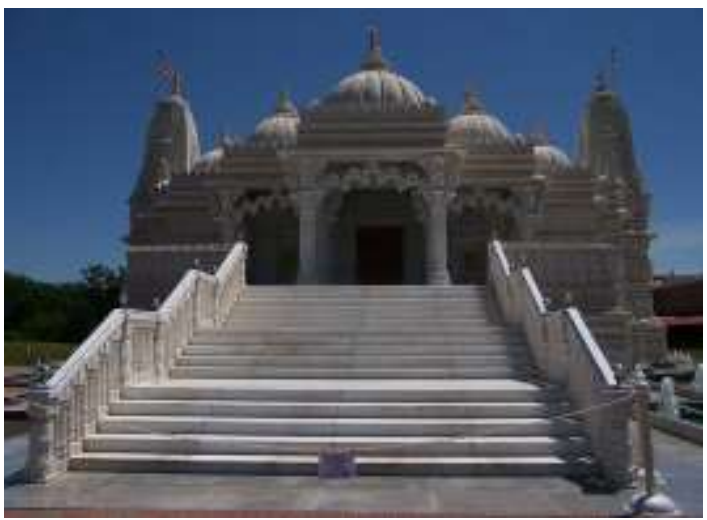

Foto 2 Baps Hindu Temple

https://commons.wikimedia.org//File:Chicago_BAPS_Shree_Swaminarayan_Hindu_Mandir.JPG 


\section{EFFECTS OF SUSTAINABLE MATERIALS IN CONSTRUCTION, ENVIRONMENT}

AND HEALTH

\section{CONCLUSION AND RECOMADITON}

Solutions to reduce the negative impact that human activities have on the environment, it is the duty of all industries. Construction as one of the largest consumers of natural resources and environmental pollutants that should be the main task. This paper presents the highlights for the creation of environmentally sustainable industry and human health, protection of natural resources, reducing $\mathrm{CO} 2$ emissions and the construction of permanent structures for the production and use of the right of construction materials.

One of the basic assumptions change in the thinking and acting of people associated with the construction materials industry of using, processing, working up to the final product.

The possibility of using alternative materials for the preparation of various materials with special emphasis-Concrete, only in case of recognition of the problems of environmental pollution from all aspects (environmental, economic, technological and social), it is possible to create a technology that is environmentally sustainable.

\section{REFERENCES}

1. P. K. Mehta: “Concrete Technology for Sustainable Development”, Concrete International, Vol. 21 ,

2. M. Qefleshi . Eko Betoni - Studim mbi përdorimin e Hirit të TEC-it Kosovë ( Fly Ash) si shtesë në prodhimin e betonit, aspekti fizik, inxhinieriko-ekonomik dhe impakti mjedisor në zvogëlimin e CO2 Tirane 2016

3. High Technical School of Professional - lecture building materials 2012

4. Vision 2030 \& Strategic Research Agenda, Focus Area Materials, Version 1, European Construction Technology Platform, September, 2005.

5. RILEM Report 22. "Sustainable raw materials-construction and demolition waste", Edited by Hendriks C. F., Pietersen H. S., The publishing company of RILEM, 2000.

6. R. Rosković, D. Bjegović"Role of mineral additions in reducing CO2 emission", Cement and Concrete Research 35, 2005,

7. P. K. Mehta: "Greening of the Concrete Industry for Sustainable Development", Concrete International, Vol.24,

8. CONWAS project, LIFE05 TCY/CRO/000114 "Development of sustainable construction and demolition waste management system for Croatia“ 2006-2008, http://www2.igh.hr/conwas/index.htm

9. D. Bjegović, D.Mikulić; N. Štirmer: "Proposal for construction and demolition waste management system in Croatia“, Life Cycle Assessment applications: results from COST action 530, Fullana, P.; Betz, M.; Hischier, R.; Puig, R. (eds.), AENOR ediciones, 2009.

10. D. Bjegović, M. Serdar, D. Mikulić: "Development of concrete as a contribution to sustainability", Networks for sustainable environment and high quality of life, Radic, J.; Bleiziffer, J. (eds.), Zagreb: Structural Engineering Conferences (SECON), 2008.

11. Breeam - The Environmental Assessment Method for Building Around the World, www.breeam.org 
Book of Proceedings

International Conference on Civil Engineering, Infrastructure and Environment

12. LEED Rating Systems, U. S. Green Building Council, 2009.

13. "Strategy for Sustainable Construction", HM Goverment, UK, June 2008.

14. P. K. Mehta: "A glimpse into sustainable ternary blended cements of the future", 50th Brazilian Concrete Congress, Salvador, Bahia, September 6, 2008.

15. M.Ahmeti lecture Building materials 2015. 